\title{
Sphenocavernous and Infratemporal
}

\section{Trigeminal Neurinomas: Surgical Series of 15 Cases}

\begin{abstract}
A consecutive series of 15 patients with trigeminal schwannomas treated surgically at the Centre Medico-Chirurgical Foch between 1979 and 1985 is reported. This report is limited to sphenocavernous (nine cases) and infratemporal (six cases) tumors. Initial clinical symptoms of these cases are detailed, including trigeminal and abducens nerve signs. Preoperative selective angiography and embolization are important adjuncts to surgical management. The surgical approach depends on the anatomic location of the tumor. Sphenocavernous neurinomas were removed through a pterionosubtemporal approach. Occasionally, infratemporal neurinomas were approached in two stages because of the need to reconstruct the skull base and prevent postoperative cerebrospinal fluid rhinorrhea. There were no operative deaths in the series and complete extirpation was achieved in all but one case. (Skull Base Surgery, Volume 2, Number 3, 1992, p. 142)
\end{abstract}

Trigeminal neurinomas have been the subject of many publications in the recent past, including both surgical management ${ }^{1-6}$ and imaging. ${ }^{7-9}$ Many authors have recommended aggressive approaches to paracavernous schwannomas to provide a better prognosis and functional result. 3,6,10 The purpose of this report is to discuss the specific problems of sphenocavernous and infratemporal trigeminal neurinomas.

\section{MATERIAL AND METHODS}

A retrospective review was made of the case records of 15 patients with histologically confirmed sphenocavernous and infratemporal trigeminal neuromas between 1979 and 1985 with a mean postoperative follow-up of 7 years.

Symptoms were present for a mean of 18 months (range, 4 months to 2 years) before diagnosis. The age at presentation averaged 33 years (range, 11 to 52 years). Clinical neurofibromatosis was present in one patient. Two patients had been previously operated on elsewhere for biopsy or subtotal removal.

\section{Symptoms and Signs}

The initial symptoms as well as clinical signs at the time of admission are listed in Table 1 (sphenocavernous neurinomas) and Table 2 (infratemporal neurinomas).

\section{Investigations}

The neuroradiologic investigation of these cases has been simplified by the advent of computed tomography (CT) and magnetic resonance imaging (MRI) and three 
Table 1. Sphenocavernous Trigeminal Neurinoma

\begin{tabular}{|c|c|c|c|c|c|c|c|}
\hline Case & $\begin{array}{l}\text { Age } \\
(y r)\end{array}$ & Sex & $\begin{array}{l}\text { Initial } \\
\text { Symptoms }\end{array}$ & $\begin{array}{l}\text { Clinical } \\
\text { Signs* }\end{array}$ & $\begin{array}{l}\text { Preoperative } \\
\text { Diagnosis }\end{array}$ & Surgery & $\begin{array}{l}\text { Follow-up } \\
\text { Complications }\end{array}$ \\
\hline $1 \mathrm{SG}$ & 18 & M & Diplopia & $\mathrm{VI}-\mathrm{V}_{1}$ & $\begin{array}{l}\text { Chordoma } \\
\text { Chondroma }\end{array}$ & Pterionosubtemporal & $\begin{array}{l}\text { Meningitis } \\
\text { Hypoesthesia } \\
V_{1}+V_{2}\end{array}$ \\
\hline $2 \mathrm{DC}$ & 39 & $\mathrm{~F}$ & Pain V2 & $\begin{array}{l}\text { Hypoesthesia } V_{1} \\
V_{2}+V_{m}\end{array}$ & Neurinoma & Pterionosubtemporal & $\begin{array}{l}\mathrm{Vm}-\mathrm{VI} \\
\text { transitory }\end{array}$ \\
\hline $3 \mathrm{JA}$ & 43 & $\mathrm{~F}$ & Diplopia & VI & $\begin{array}{l}\text { Neurinoma } \\
\text { Meningioma }\end{array}$ & $\begin{array}{l}\text { Preoperative } \\
\quad \text { embolization } \\
\text { Pterionosubtempral }\end{array}$ & $\begin{array}{l}\text { Hypoesthesia } \\
\qquad V_{2}+V_{3} \mathrm{Vm}\end{array}$ \\
\hline $4 \mathrm{NI}$ & 37 & $F$ & Diplopia & $V_{1}+$ pain & $\begin{array}{l}\text { Neurinoma } \\
\text { Meningioma }\end{array}$ & Pterionosubtemporal & $\begin{array}{l}\text { Hypoesthesia } \\
V_{2}+V_{4} V m\end{array}$ \\
\hline $5 \mathrm{BA}$ & 52 & $\mathrm{~F}$ & $\begin{array}{l}\text { Headache } \\
\text { Ptosis }\end{array}$ & $\begin{array}{l}\text { Hypoesthesia } V_{1} \\
V_{3} \text { partial }\end{array}$ & $\begin{array}{l}\text { Neurinoma } \\
\text { Meningioma }\end{array}$ & $\begin{array}{l}\text { Preoperative } \\
\quad \text { embolization } \\
\text { Pterionosubtemporal }\end{array}$ & $\begin{array}{c}\text { Hypoesthesia V } \\
\text { Transitory IIIrd } \\
\text { nerve palsy }\end{array}$ \\
\hline $6 \mathrm{ST}$ & 39 & $\mathrm{~F}$ & $\begin{array}{l}\text { Trigeminal } \\
\text { paresthesia }\end{array}$ & $\begin{array}{l}V_{2} V_{3} \\
\text { Paresthesia }\end{array}$ & Neurinoma & Pterionosubtemporal & $\begin{array}{l}\text { Hypoesthesia } \\
V_{3}\end{array}$ \\
\hline $7 \mathrm{LI}$ & 16 & $\mathrm{~F}$ & $\begin{array}{l}\text { Headache } \\
\text { Diplopia }\end{array}$ & $\begin{array}{l}\text { VI Hypoesthesia } \\
V_{1}+V_{2}\end{array}$ & Neurinoma & Pterionosubtemporal & $\begin{array}{l}\text { Anesthesia } V_{1} \\
+V_{2}\end{array}$ \\
\hline $8 \mathrm{BN}$ & 11 & $\mathrm{~F}$ & $\begin{array}{l}\text { Headache } \\
\text { Incomplete IIIrd } \\
\text { nerve palsy }\end{array}$ & $\begin{array}{l}\text { Partial IIIrd } \\
\text { nerve palsy }\end{array}$ & $\begin{array}{l}\text { Neurinoma } \\
\text { Chordoma }\end{array}$ & Pterionosubtemporal & $\begin{array}{l}\text { Hypoesthesia } \\
V_{2} \\
\text { Transitory IIIrd } \\
\text { nerve palsy }\end{array}$ \\
\hline 9 SG & 40 & M & $\begin{array}{l}\text { von Recklinghausen } \\
\text { disease }\end{array}$ & 0 & Neurinoma & Pterionosubtemporal & $\begin{array}{l}V_{1}+V_{2} \\
\text { hypoesthesia }\end{array}$ \\
\hline
\end{tabular}

$\mathrm{Vm}$ : motor trigeminal nerve palsy.

dimensional (3-D) reconstructions of these images. Selective carotid angiography provided for accurate diagnosis and aided the decision whether or not to use preoperative endovascular embolization (Fig. 1) These studies have led us to divide these 15 cases into two groups, according to their location and extension that require different surgical approaches.
The sphenocavernous neurinomas appear on CT as expanding lateral paracavernous masses that contact the sphenoid sinus anteriorly and the petrous apex posteriorly (Fig. 2)

Infratemporal neurinomas appear to destroy the floor of the infratemporal fossa from below and extend through the pterygomaxillary space (Fig. 3).

Table 2. Infratemporal Trigeminal Neurinoma

\begin{tabular}{|c|c|c|c|c|c|c|c|}
\hline Case & $\begin{array}{l}\text { Age } \\
(y r)\end{array}$ & Sex & $\begin{array}{l}\text { Initial } \\
\text { Symptoms }\end{array}$ & $\begin{array}{l}\text { Clinical } \\
\text { Signs* }\end{array}$ & $\begin{array}{l}\text { Preoperative } \\
\text { Diagnosis }\end{array}$ & Surgery & $\begin{array}{l}\text { Follow-up } \\
\text { Complications }\end{array}$ \\
\hline $10 \mathrm{SG}$ & 42 & $\mathrm{~F}$ & Facial pain & $V_{2}-V_{1}$ & $\begin{array}{l}\text { Chordoma } \\
\text { Chondroma }\end{array}$ & Subtemporal & $\begin{array}{l}\text { Meningitis } \\
\mathrm{V}_{2} \mathrm{~V}_{3} \mathrm{VI}\end{array}$ \\
\hline $11 \mathrm{TM}$ & 42 & $F$ & $\begin{array}{l}\text { Facial pain } \\
\text { Diplopia }\end{array}$ & $\mathrm{V}_{3} \mathrm{Vm} \mathrm{VI}$ & $\begin{array}{l}\text { Chordoma } \\
\text { Chondroma } \\
\text { Neurinoma } \\
\text { Malignant tumor } \\
\text { of the area }\end{array}$ & Subtemporal & $\mathrm{V}_{2} \mathrm{~V}_{3} \mathrm{Vm}$ \\
\hline 12 SAM & 23 & $F$ & Headache & 0 & $\begin{array}{l}\text { Meningioma } \\
\text { Sarcoma } \\
\text { Neurinoma }\end{array}$ & $\begin{array}{l}\text { Extradural, } \\
\text { infratemiporal }\end{array}$ & $\begin{array}{l}\text { Hypoesthesia } \\
\mathrm{V}_{2}\end{array}$ \\
\hline $13 \mathrm{FC}$ & 32 & $\mathrm{~F}$ & $\begin{array}{l}\text { Headache } \\
\text { von Recklinghausen } \\
\text { disease }\end{array}$ & $\mathrm{V}-\mathrm{VI}$ & Meningioma & Subtemporal & $\begin{array}{l}\mathrm{V} \text { incomplete } \\
\text { removal }\end{array}$ \\
\hline 14 RRM & 31 & $\mathrm{~F}$ & Facial pain & $V_{1}+V_{2}-V_{1}$ & $\begin{array}{c}\text { Neurinoma } \\
\text { (previous } \\
\text { biopsy) }\end{array}$ & $\begin{array}{l}\text { Extradural, } \\
\text { infratemporal }\end{array}$ & $\begin{array}{l}\text { Rhinorrhea } \\
\text { Meningitis } \\
\text { Partial V }\end{array}$ \\
\hline $15 \mathrm{GE}$ & 34 & $\mathrm{~F}$ & $\begin{array}{l}\text { Facial pain } \\
\text { von Recklinghausen } \\
\text { disease }\end{array}$ & $\mathrm{V}-\mathrm{VI}-\mathrm{VII}$ & $\begin{array}{c}\text { Neurinoma } \\
\text { (previous } \\
\text { biopsy) }\end{array}$ & $\begin{array}{l}\text { Two stages } \\
\text { 1. Subtemporal } \\
\text { 2. Infratemporal }\end{array}$ & $\mathrm{Vm}-\mathrm{VI}$ \\
\hline
\end{tabular}

*Vm: motor trigeminal nerve palsy. 
A
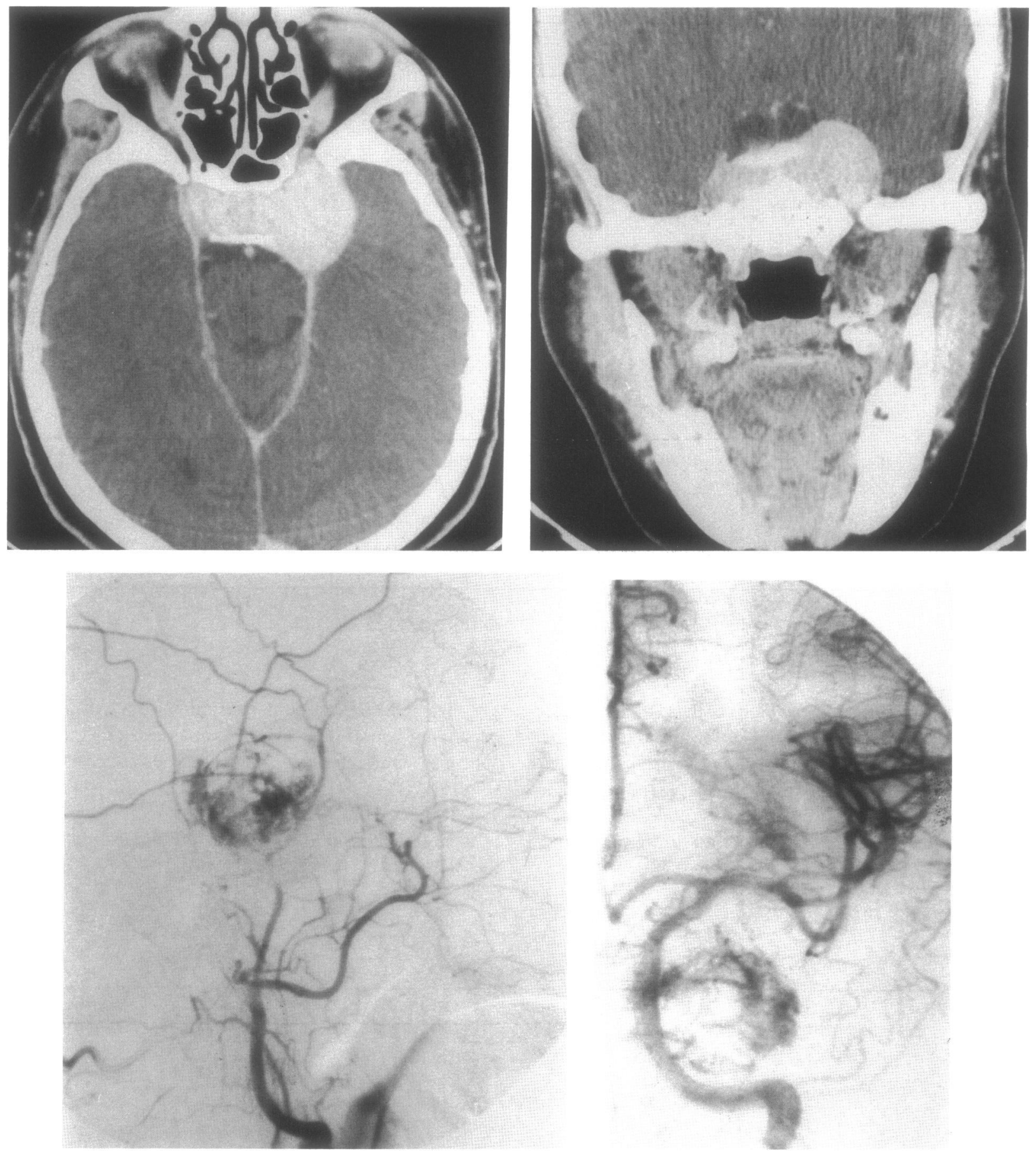

Figure 1. Case 5. A, B: Sphenocavernous trigeminal neurinoma: note the widening of the foramen rotundum. C, D: Angiography: the vascularization gets through the meningeal perforating arteries from the internal carotid siphon and from the internal maxillary artery. (Figure continued on next page)

\section{Surgical Techniques}

A pterionosubtemporal intradural approach was used in 11 cases (nine sphenocavernous and two infratemporal). Usually, opening the sylvian fissure produced sufficient brain retraction. The entrance of the oculomotor nerves into the cavernous sinus is identified and the tumor ap- incised and the remainder of the dissection is performed extradurally. Working extradurally prevents injury to the carotid artery, which was usually not clearly identified during this procedure. We did not find the use of the ultrasonic aspirator (CUSA) particularly useful in this procedure. The removal of the medial part of the tumor in the cavernous sinus always produced profuse hemorrhage. Care must be exercised in the removal of the ante- 
E

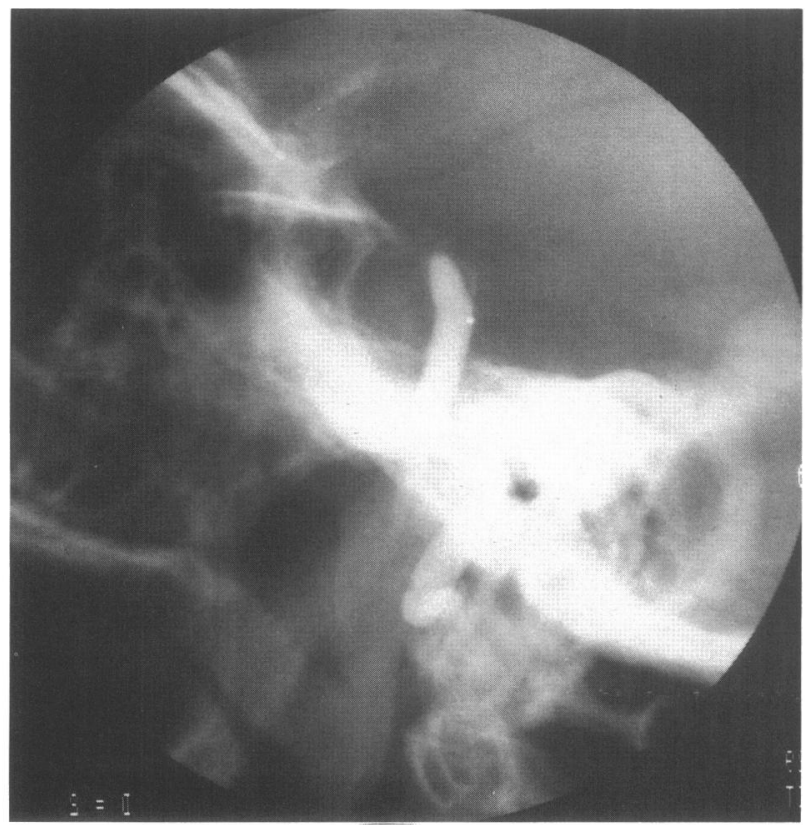

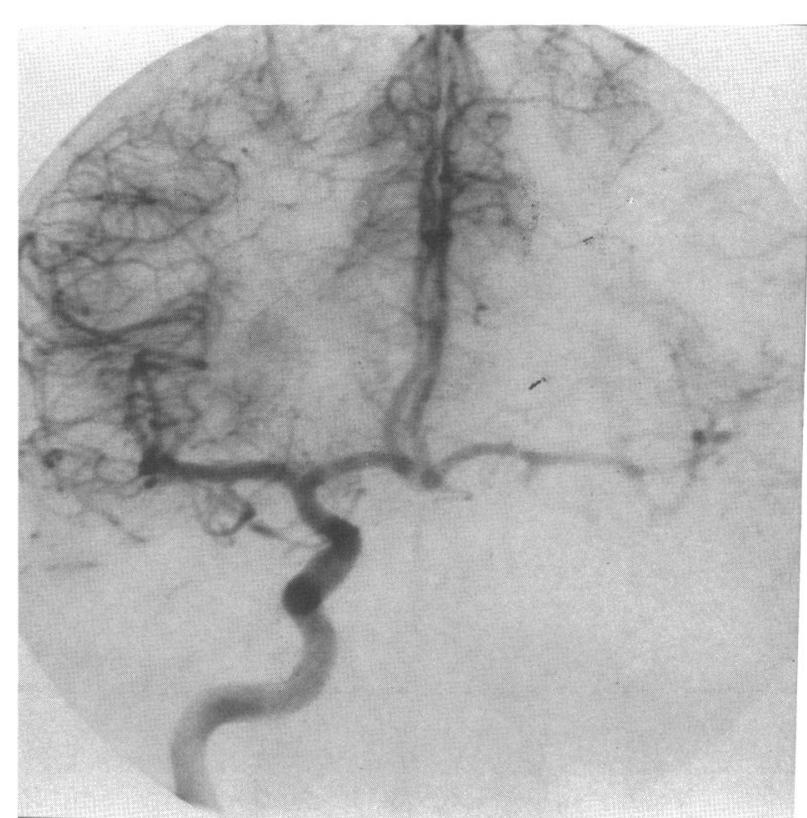

Figure 1, cont. E, F: Angiography after embolization and setting up a balloon in the intracavernous carotid artery. Arterial tumoral supply is eliminated and cerebral blood flow is maintained by the opposite side. rior medial portion of the tumor not to violate the sphenoid sinus mucosa. At the end of the procedure, the trigeminal nerve had been clearly identified and preserved in three cases. Careful repair of the basilar dura is important to prevent postoperative encephalocele and cerebrospinal fluid (CSF) leaks.

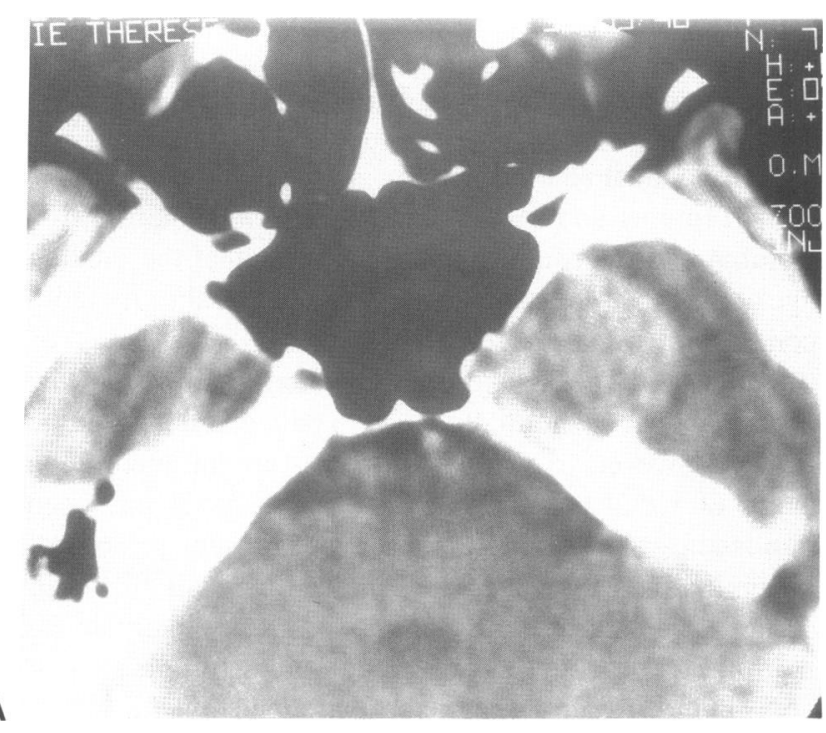

Figure 2. Case 6. A, B: Computed tomography CT scans showing internal temporobasal tumor, widening the foramen ovale, and trigeminal neurinoma of the third division.
An infratemporal extradural approach was used in two cases.

A combined two-stage approach was used in one case (15). This tumor filled the left temporal fossa and invaded the cavernous sinus. The floor of the temporal fossa was entirely destroyed and the tumor extended through

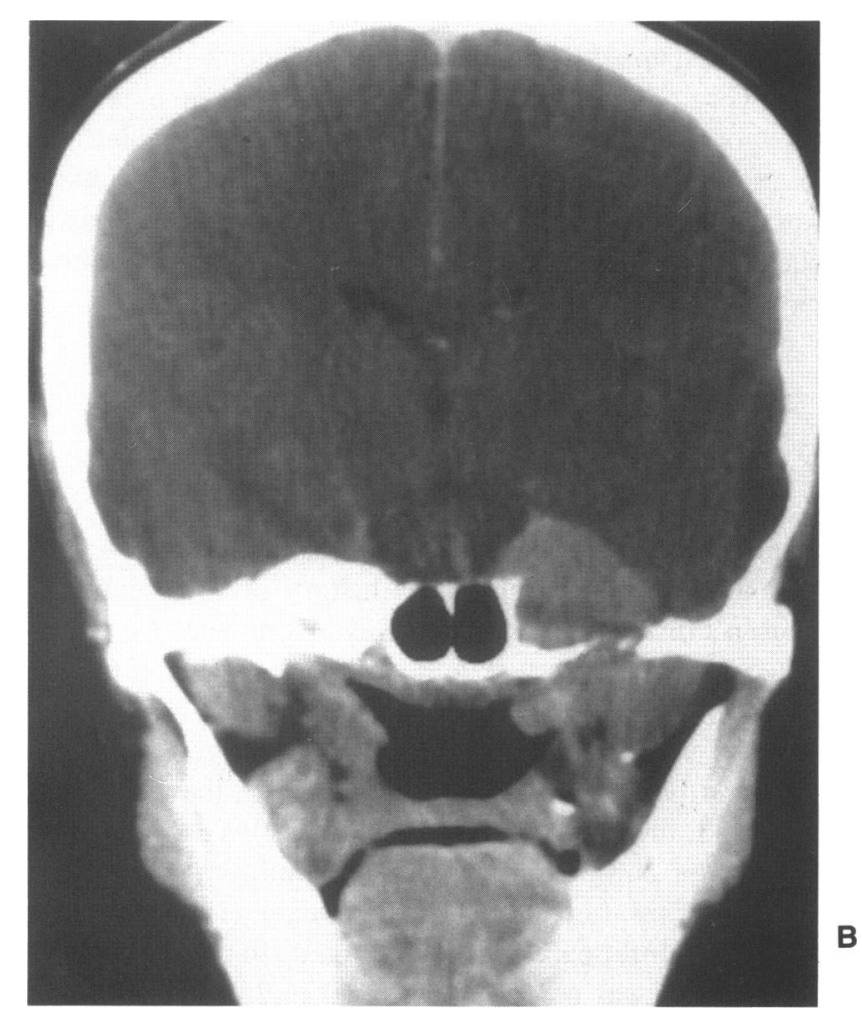



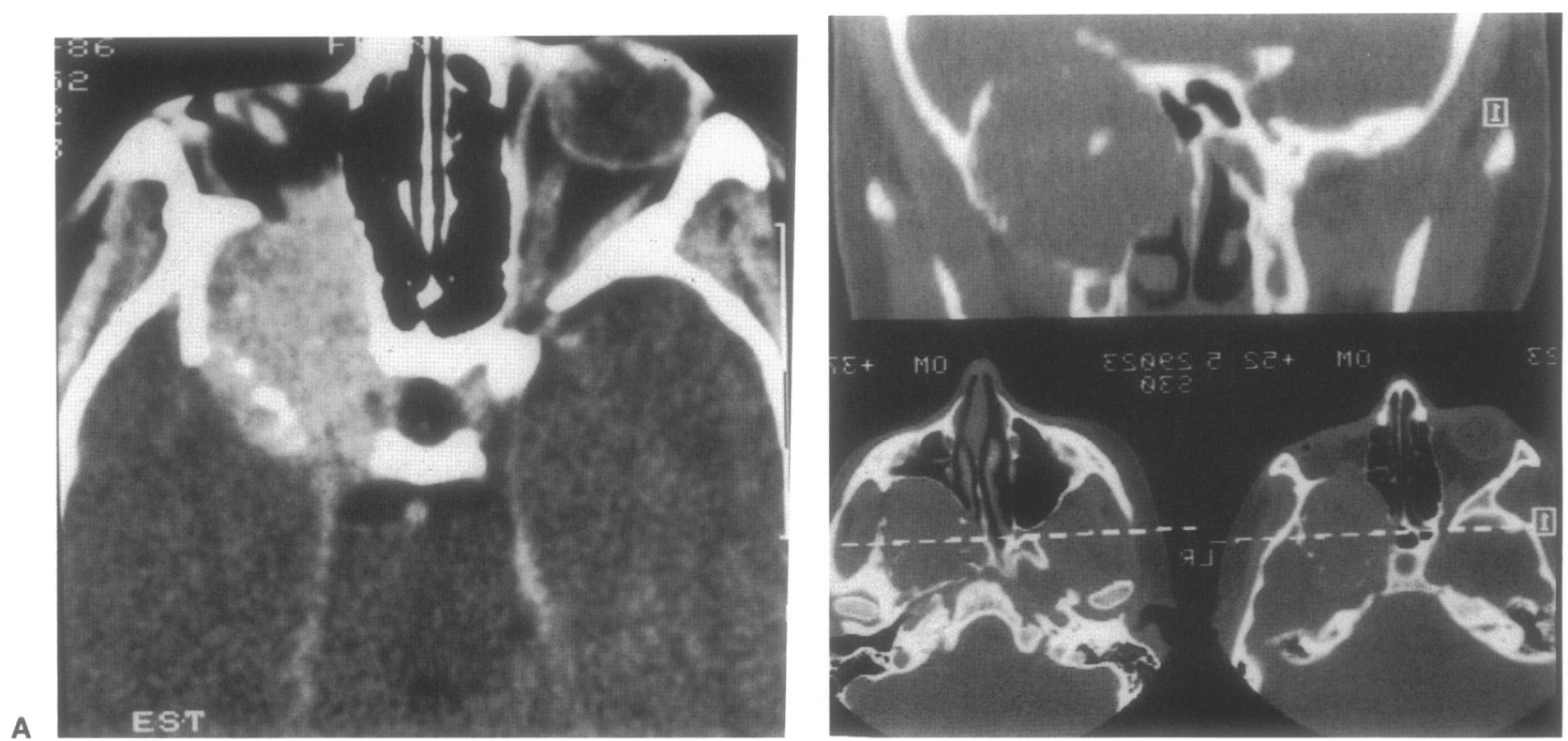

Figure 3. Case 12. A, B: Preoperative computed tomography scan. Orbitomeatal and coronal plane. Extradural infratemporal trigeminal neurinoma extending through the anterior temporal fossa, inside the orbit. Internal and inferior parts reach the cavernous sinus, sphenoidal sinus, and pterygomaxillary space (the ocular globe had been previously removed because of a retinoblastoma).

the infratemporal space into the pterygomaxillary space (Fig. 4).

Total tumor removal was achieved with two procedures separated by 3 months. In the first procedure the intracranial portion of the tumor was removed and the tumor was divided at the presumed level of the skull base. The skull base was closed by suturing the fascia of the temporalis muscle to the dura along the cavernous sinus. A sheet of Silastic was placed under this pericranium to serve as an upper landmark during the second stage operation (Fig. 4C). The second procedure was a temporozygomatic approach; the lateral part of the malar and anterior part of the zygomatic arch were divided, allowing removal of the remainder of the neurinoma. The Silastic sheath was identified at the upper level of the operative cavity and there was no CSF (Fig. 4D).

\section{RESULTS}

A total macroscopic removal of the tumor was achieved in 14 of the 15 cases. In the remaining case with an extensive neurinoma and a history of von Recklinghausen's disease, the removal was incomplete. No recurrence has been observed in the follow-up period of 6 to 12 years (mean, 6 years).

As would be expected, worsening of trigeminal function was the rule in these cases. Generally, the worsening was mild, involving the motor division (five cases), hypoesthesia of one branch (five cases), and hypoesthesia of two branches (ten cases). In one case (15), persistent residual painful paresthesia was noted. In two cases a VI
There was no perioperative mortality. A transient aphasia was observed in two cases when the subtemporal approach was used on the dominant side. Two patients developed bacterial meningitis; one with CSF leak (case 14). In this case a huge infratemporal fossa cavity filled with CSF developed because of an unrecognized opening in the prepontine cistern. The CSF leak occurred through the sphenoid sinus (Fig. 5B).

\section{DISCUSSION}

Trigeminal neurinomas represent only $0.36 \%$ of intracranial tumors and 5\% of intracranial schwannomas. ${ }^{11-13}$ Combined data from the literature show that the median age at diagnosis is 37 years and the tumor is slightly more common in women (59\%).

It would be expected that a lesion arising from the trigeminal nerve should give rise to pain or a deficit of the nerve. However, trigeminal neuromas are an uncommon cause of facial pain, a range of 0.1 to $5.5 \%$ has been published.2,3,5,6 Facial neuralgias are present in $36 \%$ of trigeminal neurinomas at the time of diagnosis. ${ }^{3,5}$ In our series, sphenocavernous tumors were less likely to be painful (two of nine) than infratemporal tumors (six of six). This difference might be explained by the higher probability of compression of the peripheral branches of the trigeminal in the infratemporal space. The facial pain is most often described as diffuse nonparoxysmal, burning pain without a trigger point. ${ }^{14,15}$ The degree of sensory loss is quite variable; $1540 \%$ of our cases, including several large infratemporal neurinomas, had no objective sensory loss on preoperative examination. This paradoxical find- 

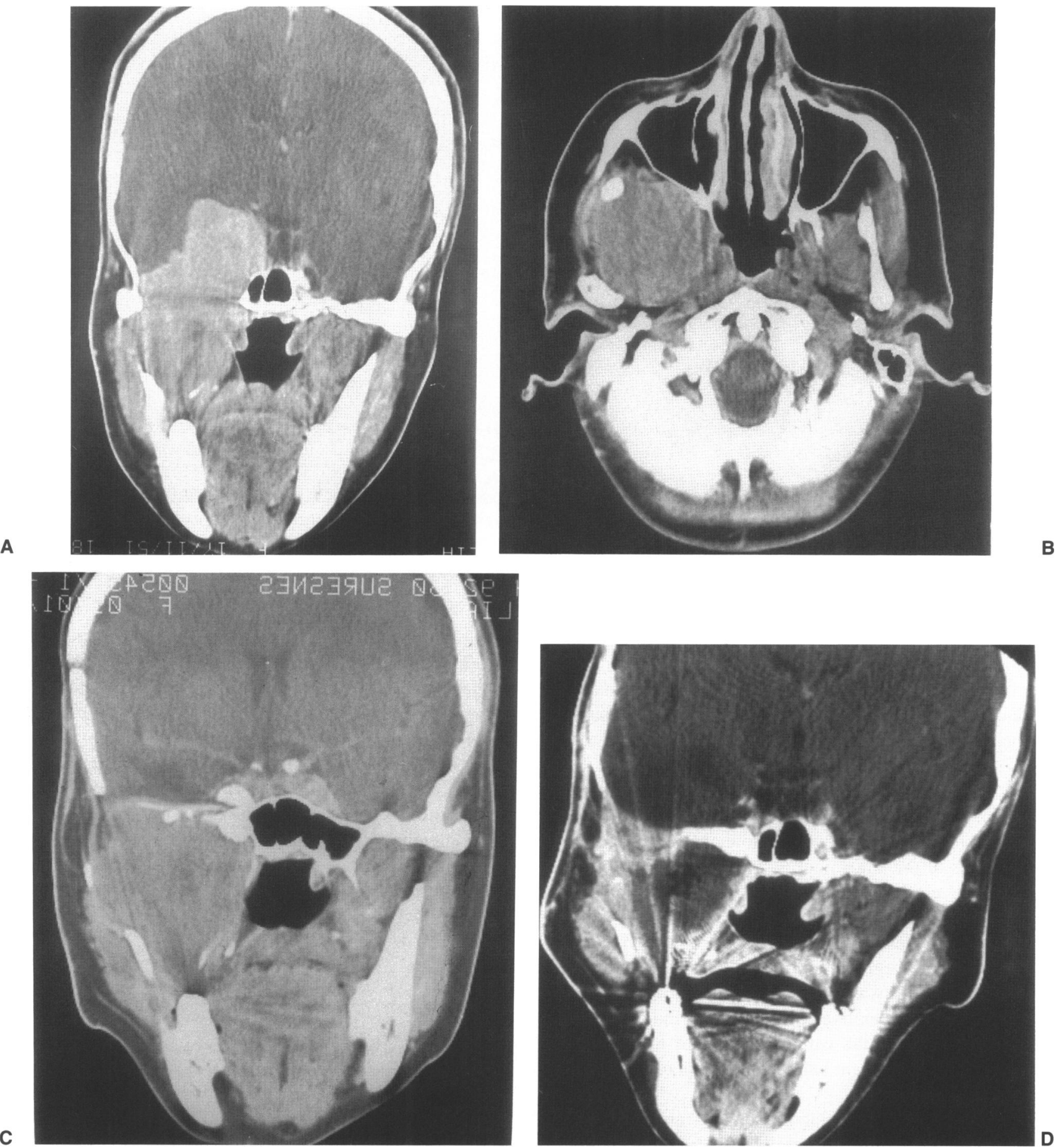

Figure 4. Case 1. A, B: Preoperative computed tomography (CT) scan: large extra- and intracranial trigeminal neurinoma. C: CT scan after removal of the intracranial part. D: CT scan after the removal of the infratemporal part of the neurinoma, 3 months after the first operation; the removal is total. The dura was watertight.

ing is classically explained by the fact that neurinomas are mainly schwannomas and nerve fibers are more likely to be pushed aside rather than destroyed. ${ }^{15}$ Diplopia is a frequent initial symptom, whereas masticatory palsy occurs late in the disease. $1,3,5,12,13,15$

From our experience, the natural history of these tumors can be outlined as follows: in sphenocavernous tumors, diplopia is the initial symptom followed by sensory loss and facial pain. In infratemporal neurinomas, pain is an early symptom followed successively by sensory loss, diplopia, and masticatory palsy.

Neuroradiologic investigations, including CT, MRI, 
A
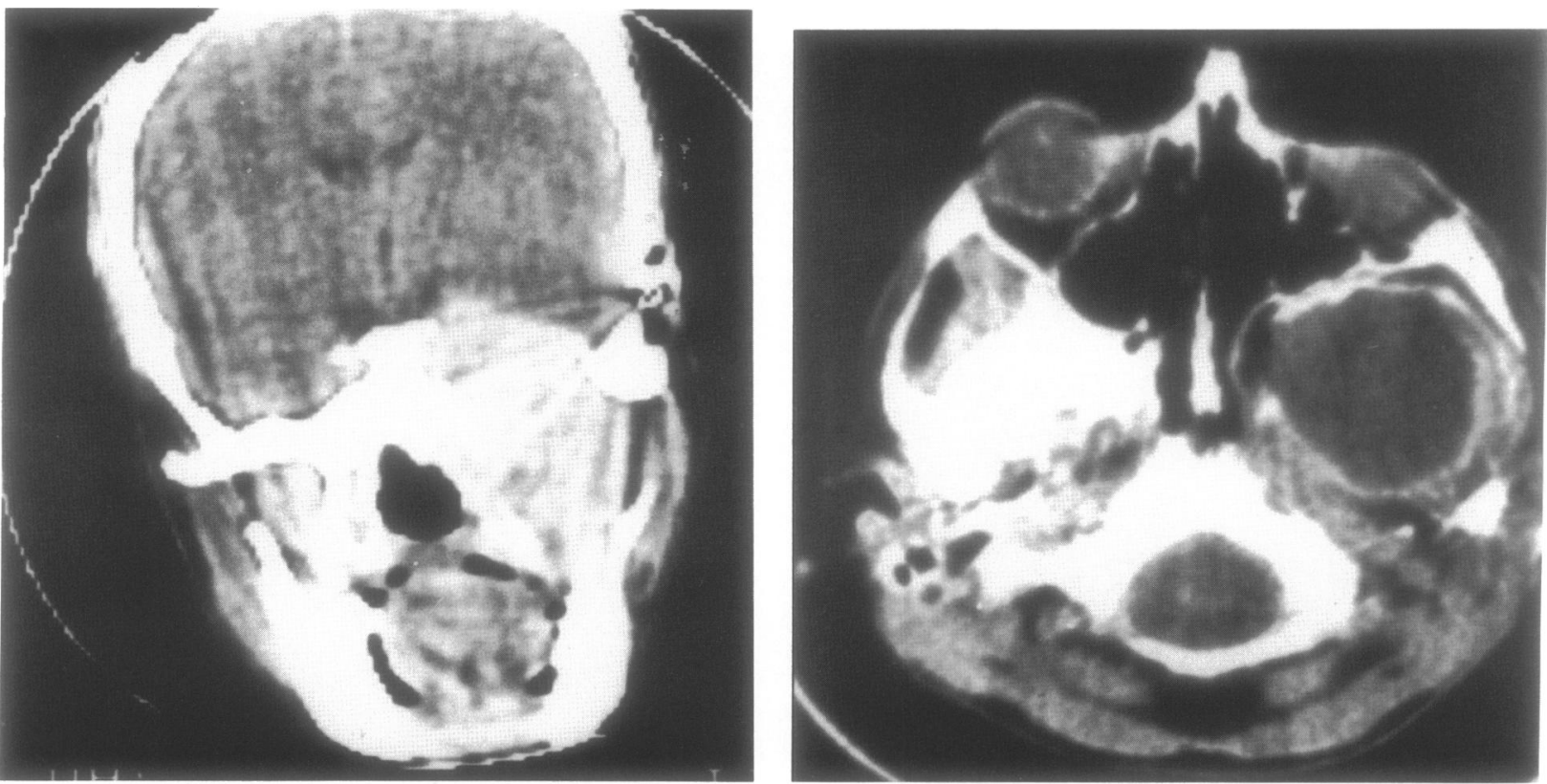

Figure 5. Case 14. A: Preoperative computed tomography (CT) scan: large infratemporal neurinoma extending into the pterygomaxillary space. B: Postoperative CT scan at the same time of a rhinorrhea. The entire postoperative cavity is filled with cerebrospinal fluid (CSF) with evidence of CSF leak into the sphenoidal cells.

3-D reconstruction, and selective angiography, will determine the anatomy of the lesion but will not make the diagnosis. In nine of our cases the differential diagnosis included chordoma, chondroma, and meningioma as well as neurinoma.

We have found that coronal CT is the most effective means of demonstrating the true extent of the lesion. MRI is useful to demonstrate the involment of one or several divisions of the trigeminal nerve. ${ }^{7}$

The usefulness of superselective angiography has been well documented.6,16-18 The feeding vessels are usually derived from meningeal arteries of the precavernous and cavernous segments of the carotid siphon, but also the internal maxillary artery and middle meningeal artery. In these cases preoperative embolization is indicated. When the feeders from the carotid artery are too tiny to be embolized, permanent balloon occlusion of the carotid is possible (Fig. 1).

When all trigeminal neurinomas are combined, a rather poor postsurgical prognosis is found in the literature. 13,15,19,20 However, recent papers advocating radical excision of paracavernous tumors $4,6,10,21$ suggest that it may now be possible to attempt removal of these tumors with acceptable morbidity and mortality. Radical removal is important because recurrence is inevitable after incomplete removal.5,6 Various surgical approaches have been advocated in the management of these tumors. $3,4,10,22$ The choice depends on the precise location of the tumor. The goals of such surgery should be to address the following points.

The meningeal plane should be preserved or recon-
The management of the carotid artery remains a surgical challenge and is dependent on the results of angiography. If there is no tumor blush and the carotid wall is normal, the tumor can be removed without violation of the carotid. Proximal and distal control of the carotid, as has been advocated by some authors, 10,22 has not been necessary in our 11 such cases. On the other hand, when angiography shows tumor blush directly from the carotid, embolization or direct surgical control of the artery must be performed.

\section{REFERENCES}

1. Beck DW, Menezes AH: Lesions in Meckel's cave: variable presentation and pathology. J Neurosurg 67:684-689, 1987

2. Bordi L, Compton S, Symon L: Trigeminal neurinoma: a report of eleven cases. Surg Neurol 31:272-276, 1989

3. Mc Cormick PC, Bello JA, Pont KD: Trigeminal schwannoma Surgical series of 14 cases with review of the literature. Neurosurg 69:850-860, 1988

4. Al Mefty O, Smith RR: Surgery of tumors invading the cavernous sinus. Surg Neurol 30:370-381, 1988.

5. Pelissou I, Sindou M, Goutelle A, et al: Neurinome du trijumeau exérèse par voie mixte sous occipitale et ptérionotemporale Neurochirurgie (Paris) 34:8-16, 1988.

6. Pollack IF, Sekhar LN, Janetta PJ, Janecka IP: Neurilemonas of the trigeminal nerve. J Neurosurg 70:737-745, 1989

7. Rigamonti D, Spetzler RF, Shetter A: Magnetic resonance imaging and trigeminal schwannoma. Surg Neurol 28:67-70, 1987.

8. Levinthal R, Bentson Jr: Detection of small trigeminal neurinomas. J Neurosurg 15:568-575, 1976.

9. Lye RH, Ramsden RT, Stack JP et al: Trigeminal nerve tumor: comparaison of CT and MRI. J Neurosurg 67:124-127, 1987

10. Sekhar LN, Moller AR: Operative management of tumors involving the cavernous sinus. J Neurosurg 64:879-889, 1986. 
11. De Beneditis G, Bernasconi V, Ettore G: Tumors of the fifth cranial nerve. Acta Neuroshir (Wien) 38:37-64, 1977.

12. Yamashita J, Asato R, Handa H: Abducens nerve palsy as initial symptom of trigeminal schwannoma. J Neurol Neurosurg Psychiatry 40:1190-1197, 1977.

13. Schisano $\mathrm{G}$, Olivercrona $\mathrm{H}$ : Neurinoma of the gasserian ganglion and trigeminal root. J Neurosurg 17:306-322, 1960

14. Fromm GH, Terrence CF, Maroon JC: Trigeminal neuralgia: Current concepts regarding etiology and pathogenesis. Arch Neurol 41:1204-1207, 1984.

15. Paillas JE, Grisoli F, Farnarier P: Neurinome du trijumeau: à propos de 8 cas. Neurochirurgie (Paris) 20:41-54, 1974.

16. Dany A, Pefferkorn JP, Vallat JN, et al: Neurinome du ganglion de Gasser à développement temporal. Neurochirurgie (Paris) 16: 349-356, 1970.
17. Gordy PD: Neurinoma of the gasserian ganglion: Report of a case and review of the literature. J Neurosurg 22:90-94, 1965.

18. Pertuiset B, Marteau R, Philippon J, et al: Neurinome du trijumeau développé dans le cavum de Meckel. Neurochirurgie 14:664$658,1968$.

19. Jefferson G: The trigeminal neurinoma with some remarks on malignant invasion of the gasserian ganglion. Clin Neurosurg 1: $11-54,1955$

20. Olive I, Stein HJ: Neurofibromas of the fifth cranial nerve. J Neurosurg 14:484-505, 1957.

21. Schubiger $\mathbf{O}$, Valavanis $\mathrm{A}$, Hayer $\mathrm{J}$, et al: Neurinoma of the cavernous sinus. Surg Neurol 13:313-316, 1980.

22. Dolenc VV: Direct microsurgical repair of intracavernous vascular lesions. J Neurosurg 58:824-831, 1983. 